\title{
Astımlı Çocukta Nadir Bir Hışıltı Nedeni: Yabancı Cisim Aspirasyonu
}

\author{
A Rare Cause of Wheezing in Asthmatic Child: Foreign Body Aspiration
}

\author{
Mahmut DOĞRU ${ }^{1}$, Fatih ÇİÇEK ${ }^{1}$ \\ 1. Zeynep Kamil Kadın ve Çocuk Hastalıkları Eğitim ve Araştırma Hastanesi Çocuk Kliniği, İstanbul, Türkiye
}

Bu olgu, 10. Çocuk Alerji ve Astım Kongresi’nde (2015) poster olarak sunulmuştur.

\section{ÖZET}

Astım genellikle kronik hava yolu inflamasyonu ile karakterize heterojen bir hastalıktır. Yabancı cisim aspirasyonu, ataklarla seyreden bu hastalığın ayırıcı taniları arasındadır. Yabancı cisim aspirasyonunda astım atağına benzer şikayetler olabilmektedir. Burada astım tanısı ile takip edilen, tedaviye rağmen düzelmeyen öksürük ve hışıltı şikayetleriyle başvuran hastada saptanan yabancı cisim aspirasyonu olgusu sunulmuştur. Bu olgularda öykü ve fizik muayene dikkatlice yapılmall ve şüpheli durumlarda tanı ve tedavi amacıyla bronkoskopi yapılmalldir.

Anahtar Kelimeler: astım; hışıltı; yabancı cisim aspirasyonu

\section{ABSTRACT}

Asthma is a heterogeneous disease, usually characterized by chronic airway inflammation. Foreign body aspiration is one of the differential diagnosis of this disease that is characterized by exacerbations. Similar complaints may ocur during asthma attacks as during foreign body aspiration. Here in, we presented a case with foreign body aspiration who was followed with a diagnosis of asthma and admitted with complaints of cough and wheezing that did not improve despite treatment. In these cases, history and physical examination should be done carefully and bronchoscopy should be performed for diagnosis and treatment in suspicious cases.

Keywords: asthma; wheezing; foreign body aspiration

\footnotetext{
İletişim:

Sorumlu Yazar: Doç. Dr. Mahmut DOĞRU

Adres: Zeynep Kamil Eğitim Araştırma Hastanesi, Çocuk Kliniği, Burhanettin Üstünel Cad. No:10, İstanbul

Tel: +90 (505) 2703514 Fax: +90 (216) 3910699

E-Posta: mdmahmutdogru@yahoo.com

Makale Geliş: 29.08..2016

Makale Kabul: 05.12.2016

DOI: http://dx.doi.org/10.16948/zktipb.304984
}

\section{GİRIŞ}

Astım tekrarlayan öksürük, hışıltı, göğüste sıkıșma ve nefes darlığ 1 atakları ile karakterize havayollarının kronik inflamatuar hastalığ1dır. Tüm dünyada sık görülmekte olup, sıklığ 1 \%1-18 arasında değişmektedir. Astımın semptomları ve havayolu kısıtlığının şiddeti zaman içerisinde değişmektedir. Alerjen veya iritan maruziyeti, egsersiz, hava durumundaki değişiklik ve viral solunum yolu enfeksiyonları gibi tetikleyicilerle semptomlarda alevlenme olabilmektedir. Öksürük, hışıltı, nefes darlığ1 ve gögüste sıkışıklık semptomlarının ilerleyici olarak artmasına ve akciğer fonksiyonlarının ilerleyici azalmasına astım atağı denilmektedir. Astım atakları genel olarak yukarıda bahsedilen tetikleyicilere bağlı gelişmektedir [1]. Yabanc1 cisim aspirasyonu çocukluk döneminde sik görülen ve erken tedavi edilmezse ölüme yol açabilen klinik acillerdendir. Genellikle 3 yaşından küçük çocuklarda görülmektedir. Bu yaş grubunda çocukların molar dişleri gelişmeden nesneleri ağızları ile tanıma davranışları ve yutma refleksinin tam olarak gelişmemesi nedeniyle YCA daha s1k görülmektedir $[2,3]$. YCA özellikle 5 yaş altında astımın ayırıcı tanısında düşünülmesi gereken patolojilerdendir. Ani başlayan semptomlar, özellikle yemek yerken ve oynarken gelişen şiddetli öksürük ve stridor, tekrarlayan akciğer enfeksiyonu ve öksürük, ve fokal akciğer bulguları olan çocuklarda YCA mutla-ka düşünülmelidir [1]. Ayrıca bronkodilataör ve antiinflamatuar tedaviye rağmen klinik bulgularında düzelme olmayan veya atakları tekrarlayan çocuklarda da akla gelmelidir [4]. Burada astım tanısı ile takip edilen, tedaviye rağmen düzelmeyen öksürük ve hıșıltı şikayetleriyle başvuran hastada saptanan yabanc1 cisim aspirasyonu olgusu sunulmuştur.

\section{OLGU}

Yirmi aylık erkek olgu,5 aydır kliniğimizde astım tanısı ile takip edilmekte olan ve koruyucu tedavi almayan hasta, öksürük ve hışıltı şikayetiyle başvurdu. 
Çocuk acil kliniğine 2 ay önce aynı şikayetlerle başvuran hasta, diş merkezde akut bronşiolit tanısı ile 1 hafta yatırılmış ve taburculukta budesonid nebul 2x250 mcg ile taburcu edilmiști. Hastanın bu tedaviyi almasına rağmen öksürük ve hış1ltıları aralıklı devam etmiş ve bol balgam çıkartmıştı. 10 günlük düzelmeden sonra tekrar şikayetleri başlamıştı. Hasta son 2 ayda $3 \mathrm{kez}$ acile benzer şikayetlerle başvurup astım atak tedavisi almıştı. Anneden alınan öykü derinleștirildiğinde olgunun 2 ay önce findık yerken aniden arka arkaya öksürdüğü ve ardından şikayetlerinin başladığı öğrenildi. Fizik muayenede genel durumu iyi olan olgunun dinlemekle sol tarafta solunum sesleri daha az, ekspiriumda uzama ve yaygın kaba ralleri duyuluyordu. Solunum sayis1 42/dak, kalp tepe atımi: 124/dak, pulse oksimetre ile oksijen satürasyonu\%93'dü. Diğer sistem bulguları doğaldı. Olgunun öykü ve fizik muayene bulgularından YCA'dan şüphelenilerek posteroanterior akciğer grafisi çekildi. Grafide sol akciğerde havalanmanın azaldığı görüldü (Resim 1). Öykü, klinik ve radyolojik bulgularla YCA olduğu düşünülen hastaya acilen bronkoskopi yapıldı ve sol ana bronştan findık parçası çıkarıldı. Yabancı cisim çıkarıldıktan sonra olgunun solunum bulguları düzeldi. Astım nedeniyle kullandığ inhale steroide 3 ay devam edilip kesildi. 6 aylık izlemde atakları tekrarlamadı.

\section{TARTIŞMA}

Astım çocukluk döneminde en s1k görülen kronik hastalıktır. Tekrarlayan öksürük, hışıltı, nefes darlığı ve göğüste sıkışıklık atakları ile karakterize olan bu hastalığın ayırıcı tanısında bulunan klinik tablolardan biri de yabanci cisim aspirasyonudur. Her yaşta olmakla birlikte özellikle 5 yaş altı astımlı çocuklarda mutlaka düşünülmelidir [1]. Ani başlayan öksürük, nefes darlığ1, yemek yerken veya oynarken gelişen semptomlarda YCA kolayca akla gelmektedir. Fakat uzamış semptomlarda veya astım tedavisine yetersiz yanitta, neden olarak daha geç düşünülmektedir. $\mathrm{Bu}$ du-rumlarda YCA şüphesiyle ayrıntılı öykünü alınması önemlidir. Her ne kadar YCA öyküsü olmadan da yapılan tetkikler sonucunda YCA saptanabilmektedir. Hastanemizde daha önce yapılan bir çalışmada YCA olan hastalar retrospektif olarak değerlendirilmiş ve olguların sadece \%25'inde YCA öyküsünün olduğu saptanmıştır [5]. Bizim hastamızda 2 aydir tekrarlayan ataklar nedeniyle başvurmuştu. Normalde kontrol edici tedavi almazken, koruyucu tedavi başlanan hastanın atakları devam etmişti. Hastanın öyküsü derinleştirildiğinde atağının aspirasyon şüphesinden sonra başladığ 1 öğrenilince bronkoskopi ile fındık parçası çıkartıldı ve hastanın klinik bulgular1 düzeldi.

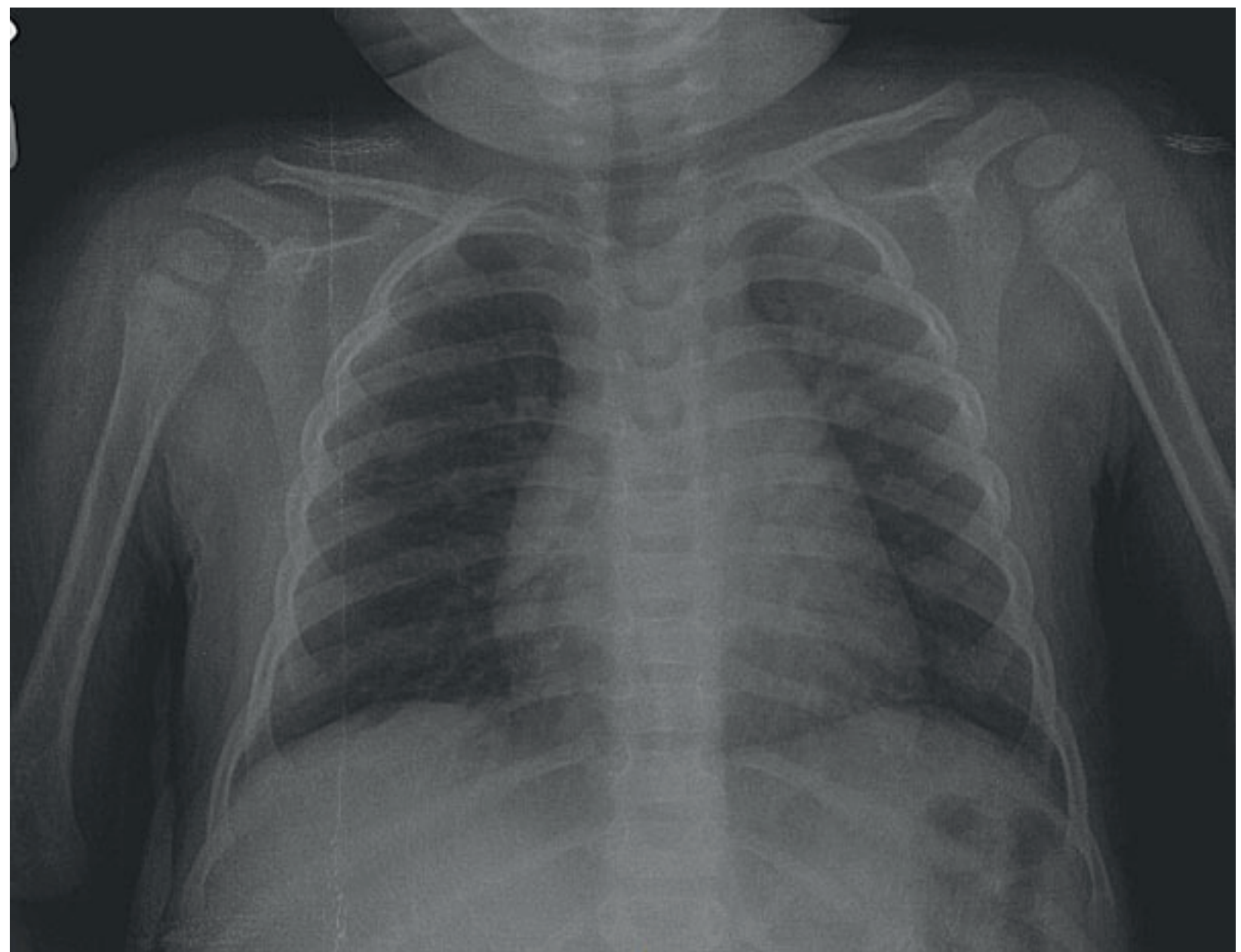


Yabancı cisim aspirasyonu çoğunlukla 1-3 yaş olmak üzere 3 yaş altında ve erkeklerde daha s1k görülmektedir [2, 3, 5, 6]. Olgumuzda literatürle uyumlu olarak 20 aylik erkek hastayd1. Yabanc1 cisim aspirasyonunda semptomlar solunum yollarındaki lokalizasyonuna, tipine ve büyüklüğüne göre değiş-mektedir. Ani başlayan solunum sikintısindan herhangi bir semptomun olmaması gibi geniş bir aralıkta semptomlar görülebilir. Klasik triad hıș1ltılı solunum, öksürük ve solunum seslerinde azalmadır [2]. Geç tanı konulan olgular pnömoni, bronşiolit, krup, tekrarlayan akciğer enfeksiyonu gibi tanılar alabilmektedirler [5]. Astımlı hastalarda hem ataklara hem de astım tedavisine yanıtsızlığa neden olabilmektedir [5, 7]. Olgumuzda benzer şekilde ilaçsız izlemdeyken anti-inflamatuar tedavi başlanmasına rağmen tekrarlayan atakları olmaktaydı. Yabancı cisim çıkartıldıktan sonra atakları 6 aylık sürede tekrarlamadı.

Aspire edilen maddenin cinsi toplumun yaşam tarzı ve beslenme alışkanlıklarına göre değişmektedir. Genel olarak çocuklarda en s1k besinler aspire edilmektedir [5]. Çocukluk döneminde YCA olan 20 olgunun değerlendirildiği çalışmada besinler \%83 olguda en s1k ç1kartılan yabancı cisimler olarak saptanmıș ve besinlerden de en sık olarak findık çıkartılmıştır [5]. Ülkemizde yeni yapılan bir çalıșmada 1982-2012 yıllar1 arasında YCA saptanan 787 olgu değerlendirilmiştir. Bu çalışmada inorganik maddeler en sık olarak olarak çıkartılan maddelerken $(\% 51,7)$ kuruyemişler en sik ç1kartılan organik maddeler $(\% 27,2)$ olarak saptanmıștır [6]. Bu çalışmanın yaș grubunun 5 ay-85 yaş olması ve olguların 339'nun 10 yaşından büyük olması nedeniyle sonuçları farklı olduğunu düşünüyoruz. Bu çalışmada yaş gruplarına göre çıkartılan yabancı cisimlerin oranları belirtilmemiştir. Olgumuzda findık parçası çıkartıldı.

Astım tedavisine rağmen şikayetleri devam eden küçük çocuklarda yabancı cisim aspirasyonu akla gelmelidir. Bu olgularda öykü ve fizik muayene dikkatlice yapılmalı ve şüpheli durumlarda tanı ve tedavi amaciyla bronkoskopi yapılmalıdır.

\section{KAYNAKLAR}

1. GINA Report, Global Strategy for Asthma Management and Prevention (2016). Available from: http://ginasthma.org/2016-gina-report-global-strategy-for-asthma-management-and-prevention/

2. Salih AM, Alfaki M, Alam-Elhuda DM. Airway foreignbodies: A criticalreview for a common pediatric emergency. World J EmergMed. 2016;7(1):5-12

3. Ciftci AO, Bingöl-Kologlu $M$, Senocak $M E$, Tanyel FC,Büyükpamukçu N. Bronchoscopy for evaluation of foreign body aspiration in children. J Pediatr Surg; 2003;38(8):1170-1176

4. Babayiğit A, Ölmez D, Demirpençe S, Uzuner $N$, Türkmen M, Karaman Ö. Bronkodilatatör Tedaviye Yanıtsız Hışıltılı Çocuk. Dokuz Eylül Üniversitesi Tıp Fakültesi Dergisi 2007;21(3):177180

5. Ünlütürk Ö, Temel Ö, Inalhan M, Yıldız F. Çocukluk Çağl Yabancı Cisim Aspirasyonlart: 20 Vakanın Analizi. Zeynep Kamil Tıp Bülteni 2010;41(1):29-33

6. Ylldırım $M$, Demirbağ $H$, Ustaalioğlu $R$, Anbar R, Yardımcı H, Okay T, Doğusoy I. Trakeobrobşiyal yabanci cisimler: 787 olgunun degerlendirilmesi. Turkish Journal of Thoracic and Cardiovascular Surgery 2016;24(3):501-506

7. Dibek Misırlıoğlu E, Erdoğan D, Çınar HG, Bostancı I. Astım Tanılı Süt Çocuğunda Hışıltı Ile Acil Başvuru Nedeni Astım Atak Ml, Yabancı Cisim Aspirasyonu Mu? Turkish J. Pediatr. Dis. 2012;6(3):176-179 